\title{
History of a Thirteenth Century Copper Mine.
}

A RECENT and most interesting gift to the Society comprises two beautifully illustrated volumes of historical material from what is possibly the oldest business enterprise in existence, the famous Swedish copper mine, Stora Kopparberg. The books are a gift

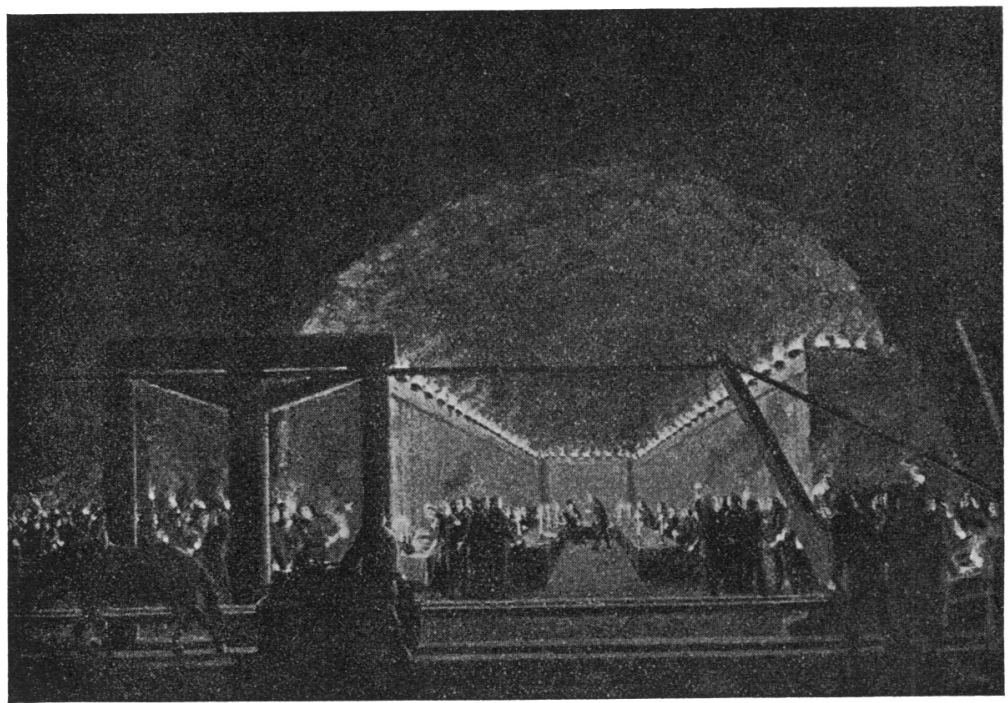

Visit of King Gustaf III to the Falun Mine in 1788

"Far up in front," runs the description of this picture as translated from the Swedish, "is the King, and towards him comes a man bowing. In the foreground one can see workers with their torches and a wagon with coal on it drawn by a horse."

from the company. It was established in the decade of the I 280 's. A study of the history of this old company, by Dr. Henrietta Larson, will be published in a future issue of the Fournal of Economic and Business History.

The English summaries which follow the Swedish text describe the first volume as treating in part certain fundamental problems in the history of Swedish mining, and in part a general survey of historical literature concerning Stora Kopparbergs Bergslag. The first 


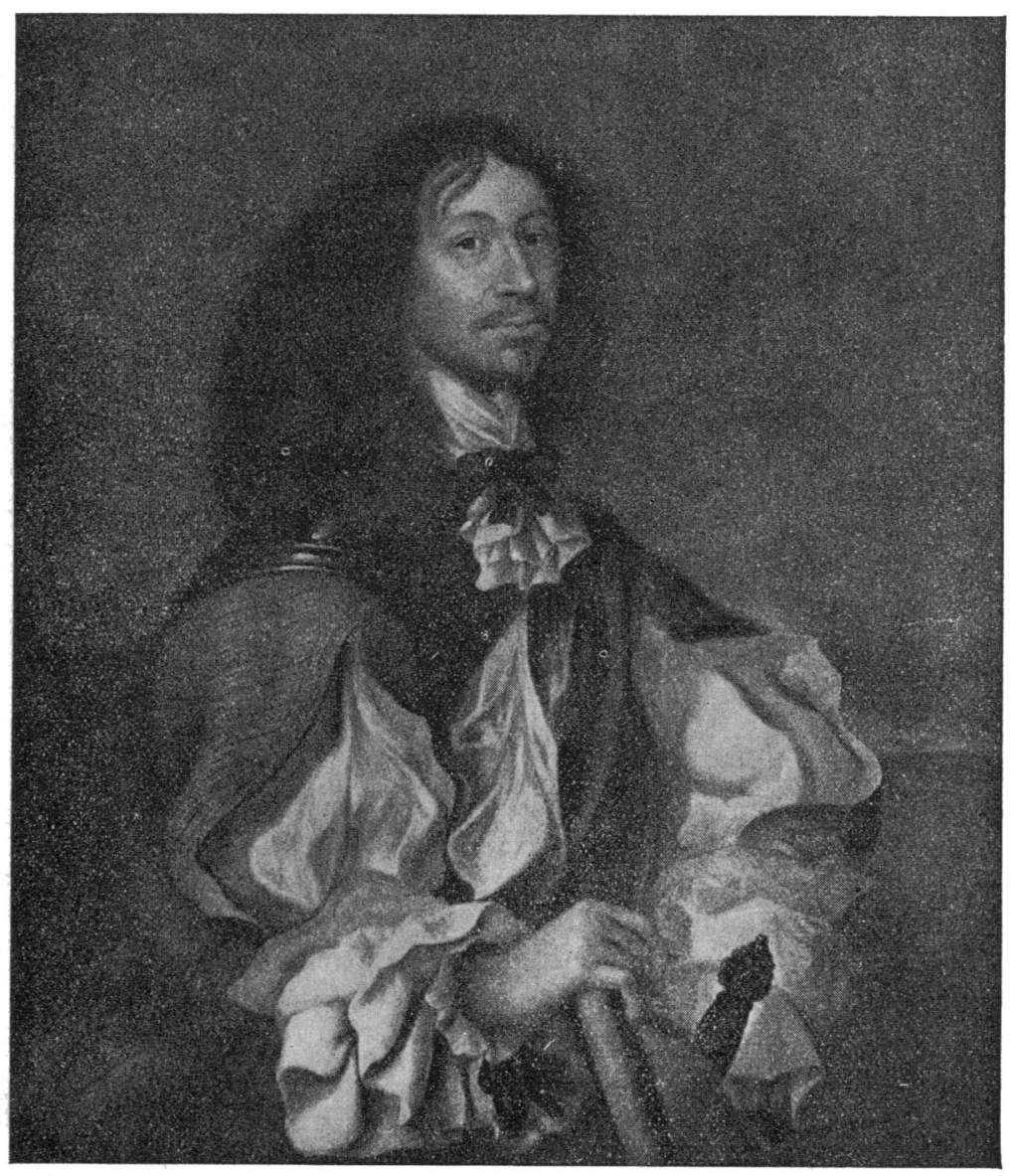

\section{Portrait of One of the Officials of Stora Kopparberg}

Claes Anckarstrom, who was inspector of the mines, in 1654, for the Swedish copper mining company which is possibly the oldest business enterprise in existence. The description given of the picture says that he was also "keeper of the books," (secretary). He was "dressed in a red gown stitched with gold. His hair was Jong and dark brown." 
chapter deals with the origin of Swedish mining, the second with the development of a separate mining district from certain parts of the province of Dalecarlia. The third follows references to Stora Kopparberg in literature from the earliest ones at the beginning of the seventeenth century.

The second volume contains biographical material, and portraits of personages who have been connected with the mine, in addition to a number of royal portraits, procured by the company in $165^{8}$, when the collection was founded. It is one of the oldest in Sweden. To quote from the summary: "The main part of it is placed in the magnificent state apartment of the Company with neighboring rooms in the head office building at Falun; it presents a splendid symbol of the development of the powerful corporation during the last three centuries. The numerous portraits illustrate its history."

\section{An Unpublished History}

THE first use of fire for heating or cooking purposes by primitive man marked a long step toward civilization. In historical times, the discovery that coal could be used instead of wood was less revolutionary in its effects, but it meant a great advance in efficiency. The unpublished manuscript of a history of the coal stove has been presented to the Society by Miss Helen E. Keep, the daughter of its author. It reveals unexpected elements of the picturesque in the evolution of this highly practical invention.

William John Keep, the author, was himself connected with the manufacture of stoves. Through his book, Cast Iron, he was recognized as an authority on that material, and his discovery of the mechanical analysis for it, known as "Keep's Test," has been widely used in this and other countries instead of chemical analysis. He had planned to put the information collected in the course of his experience in stove manufacture into permanent form in the fiftieth year of his connection with the industry, and his unpublished book was the result. The earlier chapters, particularly, are full of curious bits of information.

While the commercial value of coal was appreciated earlier, by brewers and others who needed large quantities of fuel for their occupations, coal did not come into domestic use in England until about 1600 , on account of a common prejudice to the effect that burning it contaminated the air and injured the health. Indeed, in 